\title{
Trade and Environment: In re Trade Practices Manntained by Brazil in Relation to Imports of Retread Tires
}

\author{
Fabio Morosini* \\ Cláudia Lima Marques ${ }^{* *}$
}

\section{INTRODUCTION}

The linkage between trade and environment is one of the most heated debates in international economic law. The amount of scholarly wtitings is massive, ${ }^{1}$ as well as public policies geared toward actual and potential environment and trade clashes. ${ }^{2}$ Last but not least, trade panels have had the opportunity to address some of the conflicts involved in trade and environment disputes, issuing unsatisfactory decisions in the view of environmentalists.

- Visicing Professot at the Graduate School of Law (Estratliygaion of the Universidade Federal do Rio Grande do Sul (UFRGS) and Pontifficia Universidade Católica de São Paalo (PUC-SP). Ph.D. Candidate and LCLM., University of Texas at Austin (EUA) and Mater Profersionel, University of Paris $I$ (PanthenSorlinno) and Institute of Political Srudies of Paris (Shates Po) (France). CAPES Foundation Fellow:

** Professot of international law at the Federal University of Rio Grande do Sul - UFRGS (Brazil), Dr. Iur, University of Heidelberg (Germany) and LL.M., University of Tübingen (Germany).

1 For some leading cxamples, see John M. Jackson, World Trate Rules and Enmiranmental Policier: Congruente or Conflict? 49 Wash. \& Lee L. Rev. 1227 (1992); DANIEL C. ESTY, GREENING THE GATT: TRADE, ENVIRONMENT AND 'TJE FUTURE (1994); Thomas Schoenbaum, International Trade and Pmitetion of the Enmiramment: The Continuing Search for Reconriliation, 91 Arn. J. Trut1 L. 268 (1997); Robert E. Hudec, GATT Legal Restraints on the Use of Trats Measures against Forkign Emironmental Pratices, in 2 FAIR TRADE AND HARMONIZATION 95 JAGDISH BHAGWATI \& ROBERT HUDEC EDS. 1996). Far a shady on the actual role of trade leverage in promoting environmental cooperacion in practice, see DUNCAN BRACK, INTERNATIONAL TRADE AND THE MONTREAL PROTOCOL xwi (1996) (contradicting: the convertional wisdom that environmental trade leverage is either unnccessary or ineffective.)

2 For a more policy-oriented approach of the many debates within the trade and environment conflict, see Gregory Shaffer, The World Trade Organiation under Challenge: Demarno and the Law and Politics of the WTOS Tratmint of Trade and Eminomint Matten, 22 Harv. Envt. L. Rev. 1 (2001). 
In analyzing trade and environment disputes, one is usually confronted with the following concerns: ${ }^{3}$ Is economic integration through trade a threat to the environment? Does trade undermine the regulatory efforts of governments to control pollution and tesource degradation? Will economic growth driven by trade help us to move towards a sustainable use of the world's environmental resources?

This article exanines the trade and environment debate in the context of a very recent dispute that has arisen with respect to a Brazilian ban on the import of retread tires. Recently Brazil banned imports of tetread tires and Uraguay challenged the consistency of the Brazilian measures in face of MERCOSUR law. A panel, constituted to decide the dispute, concluded the Brazilian measures were inconsistent with MERCOSUR law and ordered Brazil to eliminate the ban within MERCOSUR countries.

Immediately after the MERCOSUR decision was rendered, the EU, a major retread tire exporter, challenged the Brazilian measures as inconsistent with the 1994 General Agreement of Tariffs and 'Trade (GATT). After unsuccessful diplomatic negotiations between Brazil and the EU, the dispute was submitted to the Dispute Settlement Body (DSB) of the World Trade Organization (WTO) for consultation. In January 2006, a WTO arbitration panel was established to decide the dispute.

In 2005, again at the request of Uruguay, another MERCOSUR panel has been constituted to examine Argentinean measures, concerning practices maintained by Argentina affecting trade in retread tires. Surprisingly, the Panel found that the Argentinean measures were in accordance with MERCOSUR law, given that they aim at protecting the environment and public health. However, for the first time in MERCOSUR history, the Appellate Body exercised its jurisdiction, in response to Uruguay's appeal, and revoked the panel's decision.

PART I of this article will address the most relevant trade and environment scholarship and the development of selected trade and environment/ public health jurisprudence in the GATT/WTO.

PART II will deal with the MERCOSUR dispute over trade in rettead tires, explaining the specific products banned by Brazil, the televant treaty provisions under which the import ban was reviewed by the MERCOSUR arbitration panel, and the consequent regulatory changes produced in donestic law.

PART III will address WTO dispute over trade in retread tires, setting out the specific provisions of the WTO agreements tbat the Eutopean Communities (EC) contend are curtently being violated by the Brazilian ban, along with a description of the way in which these provisions have been interpreted by previous decisions of the WTO panels and Appellate Body. Finally, Part TV concludes the article.

3 Se HAKAN NORDSTROM \& SCOTT VAUGHAN, WTO SECRETARIAT SPECIAL STUDIES NO. 4 TRADE AND ENVIRONMENI'1.7 (1999), APUA JCKSON, JOHN H. ET AL, LEGAL PROBLEMS OF INTERNATIONAL ECONOAIC RELATYONS: CASES, MATERLALS AND TEXT 1008 (2002). 


\section{PART I.}

\section{REVIEW OF TRADE AND ENVIRONMENT LITERATURE AND JURISPRUDENCE}

Professors Edith Brown Weiss and John FI. Jackson lay out the main types of clashes involved in environment and tade disputes: ${ }^{4}$ (1) national measures to protect the domestic envitonment, (2) unilateral national measures to protect the environment outside national jurisdiction, (3) international (multilateral) envitonmental agreements and the WTO, and (4) the product/ process distinction.

\section{National Measures to Protect the Domestic Environment}

Under this category of trade and environment conflict, States adopt environmental laws or regulations and foreign parties challenge these measures in face of their inconsistency with the text of GATT 19994 or the Agreements on Technical Barriers to Trade (TBT) and on the Application of Sanitary and Phytosanitary Measures (SPS). The rationale for such types of measures normally is that "the product is restricted for sale domestically, and imports should not be able to threaten human health and the envitonment in ways that the same domestic products cannot.".

4 SeEDTTHBROWN WEISS \& JOHN H JACKSON, RECONCIING ENVIRONMENT AND TRADE 27.28 (2001). For a somewhat different conceptualization of the envitonment and tade conflict, see Joost Pauwelyn, Recent Books on Trade and Entironment: GATT Phantoms Still Hawt the WTO, European Journal of Intemational Law (2004), Vol.15 No. 3, 575. Pawwelyn divides the tension between trade and environment in the following manner: "First, treaties liberalizing trade can ham the envitonment. In this sense, trade and environment may conflict in at least four ways:

(I) more trade and economic acrivity may result in mote environmental degradation;

(II) the competition brought about by free trade may put pressure on governments to lower: environmental standards (the so called 'race to the bottom');

(III) trade agreements may prevent govetrments from enacting certain environmental regulations; and

(IV) trade law may prohibit the use of trade sanctions of preferences, be it as sticks or carrots to ensure the signing up to, or compliance with (international) environmental standatds.

Second, trade restrictions or distortions can harm the environment. In this sense, trade liberalization and environmental protection go hat in hand in at least three ways:

(I) trade liberalization should lead to bigher levels of development and make available resources for environmental protection (the Environmental Kuznets Curve);

(ii) trade-distorting subsidies and other support for over-production (activities generally disliked by trade law), be it in the fisheries or agricultural sectors, car deplete environmental resoutces; and

(III) trade testrictions on the provision of cross-botder services or technology to recycle or otherwisc limit environmental hatm can delay or prevent the efficient protection of the enviromment." Id. at 578 .

5 ld. at 28. 
This category of conflict has been brought to the attention of GATT and WTO dispute settlement mechanisms in three prominent disputes: the Thai Cigarette Case, ${ }^{6}$ the Reformulated Gasoline Case, ${ }^{7}$ and the Beef Hormones Case.

In the Thai Cigarette Case (a pre WTO case), the main issue under consideration was whether or not the Thai restrictions on the import of tobacco and tobacco products were legitimate measures to protect public health.

The US argued that the restrictions on imports of cigarettes by Thailand were inconsistent with Article XI of the GATTI 1947, which provides for the general elimination of quantitative restrictions. In addition, the complaining party alleged that the Thai measures were not justified by the exceptions contained in Article XI:2(c), which exempts certain agticulnaral products from the prohibition on the use of quantitative restrictions, or under Article XX(b), which allows the use of measures necessary to protect human health. Lastly, the US argued that Thailand's Protocol of Accession did not cover the Thai measures, and that Thailand's excise tax, and its business and municipal taxes on cigarettes were inconsistent with GATT Articles III:1 and III:2, which require national treatment of internal taxation."

The Panel held that the Thai measures were a quantitative restriction on the importation of cigatettes inconsistent with Article XI: 1 and not justified under Article XI:2(c), Article XX(b), or Thailand's Protocol of Accession.

In the Reformulated Gasoline Case, ${ }^{10}$ the US Environmental Protection Agency issued a regulation distinguishing between two types of baselines to assess gasoline quality: individual baselines, which represent the quality of gasoline produced by a specific refinet, and statutory baseline that reflects average US 1990 gasoline quality.

The Regulation did not provide for the possibility of using individual baselines for other domestic or foreign refiners. In some cases, the individual baselines were more advantageous than the statutory baseline.

"Thailand - Restrictions on Importation of Internal Taxes on Cigarettes. Adopted on 7 November 1990, GATT B.IS.D. (37 $7^{\text {th }}$ Supp.) at 200 (1991).

? United States -. Standards for Reformulated and Conventional Gasoline: Repott of the Appellate Body, WT/DS2/AB/R (Apt. 29, 1996).

- Report of the Appeliate Body, EC Medsures Concening Meat and Meat Products (Hormones), WT/ $\mathrm{DS} 26 / \mathrm{AB} / \mathrm{R}$ and WT/DS48/AB/R, AB-1997-4 (16 Jan. 1998).

" "The "national treatment" clause in trate agreements was designed to cusure that internal. fiscal or administrative regulations would not introduce discrimination of a nontariff nature. It forbids discriminatory use of the following: taxes of other internal levies; laws, regulations, and decrees affecting the sale, offer for sale, purchase, transport, distribution,..." Encyclopacdia Britannica, ulisiluble at http://wwwbritunnica,com/eb/article-61721. (last visited Jan. 16, 2005).

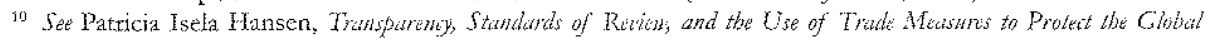
Emironmeth [hereinafter Transpormey], 39 VA. J. INTL L. 1017, 1048 (1999). 
Venezuela and Brazil brought a claim to the WTO, alleging that the US regulation violated Articles I:1 (General Most-Favored-Nation Treatment), ${ }_{11}^{11}$ III:1 and III:4 (National Treatment on Internal Taxation and Regulation), Articles 2.1 and 2.2 of the Agreement on Technical Bartiers to Trade (TBT), relating to the preparation, adoption and application of technical regulations, and nullification and impairment of benefits.

The Panel held that the Gasoline Regulations were inconsistent with Article III:4 of the GATT, which requires that imported like products must be treated no less favorably than like domestic products with respect to laws and regulations. Moreover, the Panel concluded the US measures wete not justified under the exception of Article XX(g) of GATT 1994, as a measures telating to the conservation of exhaustible natural resources.

The Appellate Body reversed the Panel's findings that the measures did not fall within the scope of Article XX (g). In the Appellate Body's opinion, the measures fall under the exception of Article XX $(\mathrm{g})$, but failed to meet the requitements of the Chapeau of Article $\mathrm{XX}$. The Chatean of Article XX prorjdes that a measure may not be applied in a manner that would constitute a means of arbitrary or unjustifiable discrimination between countties where the same conditions ptevail, or a disguised restriction on international trade.

In the Beef Hormones Case, the Eutopean Communities (EC) adopted the Councl Diretive Probibiting the Use in Livestock Farming of Certain Substances Having a Hormond Action.

13 Most-Favor-Nation Clause (MFN): "provision in a commercial treaty binding the signatories to extend trading benefits equal to those accorded any third state. The clause ensures equal commercial opportunities, especially concetring import duties and freedom of investment. Generally reciprocal, in the late 19th and early 20th cent, unilateral MFN clauses were imposed on Asian nations by the more powerful Western countries (see Open Door). In the late 20 th cent. tarift and trade agreements were negotiated simultaneously by all interested parties through the General Agreeraent on Tariffs and Trade (GATI), which ultimately resulted in the World Trade Organization. Such a wide exchange of concessions is intended to promote ftee trade, although there has been criticism of the principle of equal trading opportunities on the grounds that freer trade benefits the economically strongest countries. GATT members recognized in principle that the MFN rule should be relaxed to accommodate the needs of developing countries, and the UN Conference on Trade and Developmont (est. 1964) has sought to extend preferential treatnent to the exports of the developing countries. Another challenge to the MFN principle has been posed by regional trading groups such as the European Union, which have lowerd or eliminated tariffs anong the members while maintaining tariff walls between member nations and the rest of tbe world. In the $1990 \mathrm{~s}$ continued MFN status for China sparked US. controversy because of its sales of sensitive military technology and its use of prison labor, and its MEN status was only made permanent in 2000. All of the former Soviet states, including Russia, wete granted MFN status in 1992." See The Columbia Encyclopedia, Sixth Edition. 2001-05. The general scope of the MFN obligation was discussed by the Appellate Body in EUROPEAN COMMUNTTIES - REGIME IOR THE IMPORTATION, SALE AND DISTRIBUTION OF BANANAS, WT/DS27/AB/R, adopted by the DSB on Septembet 25, 1997. 
The US challenged the European measure based on the Sanitary and Phytosanitary Agreement. The Agreement permits countries to take food and safety measures, provided several conditions are met, such as: SPS measure be based on sufficient scientific evidence (Article 2.2), and risk assessment (Article 5.1). While the SPS Agreement encourages harmonization of SPS measures (Article 3.1), it allows the maintenance of measures resulting in a higher level of protection than would be achieved by international standards (Article 3.3).

To the US and Canada, the EC measures, by restricting or prohibiling the importation of meat and meat products from the US, violated Article III (requiring national treatment) and XI GATT (prohibiting quantitative restrictions), Articles 2, 3 and 5 of the SPS Agreement, Article 2 of the Agreement on Technical Barriers to Trade (on the preparation, adoption and application of technical regulations), and Article 4 of the Agreement on Agriculture (on market access commitments).

The Panel only examined the claims brought under the SPS Agreement and held the EC measures to be inconsistent with Articles 3.1,5.1 and 5.5 of the Agreement. The Appellate Body confirmed the Panel's finding that the EC import ban was inconsistent with Article 5.1 (requiting risk assessment).

\section{Unilateral National Measures to Protect the Environment Outside Nátional JuRisdiction ${ }^{12}$}

According to Weiss and Jackson, ${ }^{1,3}$ the main characteristic of this type of measures is that it is unilateral in that sense that they are not taken pursuant to implementing an international or multilateral agreement. Reasons such as a country not wanting to watch helplessly as a species identified as endangeted by an international agreement forced into extinction by fishing methods that destroy the animals as by-catch may warrant a clash between environment and trade interests. ${ }^{1 *}$

Principle 12 of the 1992 Rio Declaration on Environment and Development addressed the issue of unilateral national measures aimed at protecting the environment outside national jurisdiction. ${ }^{15}$

12 See getterully Hansen, Trumpureng; supra note 10 (arguing that exvitonment and trade disputes may be reduced if governments adopt more transpatent decisionmaking procedures.) See also Richatd W. Parker, The Use and Abuse of Trade Loterage to Protet the Glabal Commons: What Can We Latam from The TasmaDilptin Conflit, 12 GEO. INT"L ENVIL. L. REV. 1 (1999) (concluding there ate more pro than cons in the use of environmental trade leverage.)

13 See BROWN WEISS \& JACKSON, supra note 4, at 29.

${ }^{14}$ Id

15 Principle $12 ; \ldots$ "Unilatetal actions to deal with environmental challenges outside the jurisdiction of the importing country should be avoided. Environmental measures addressing Transboundary or global envirotamental problems should, as fas as possible, be based on an international consensus." 
This type of environment and trade conflict has been tested in the Tuna-Dolphin I, ${ }^{16}$ 'Tuna Dolphin-II, ${ }^{17}$ and Shrimp-Turtle Cases. ${ }^{18}$

'Tuna-Dolphin I and II Cases addressed the consistency of U.S. measures to protect the Eiastern Spinner Dolphin from fishing by purse seine nets, concluding that the measures were inconsistent with the GAT'T. The Panel in Tuna-Dotphin I rejected the US arguments for extraterritorial application of the Article XX (b) and (g) exceptions, ${ }^{19}$ but the Panel in TunaDolphin II allowed for the possibility of extraterritorial application of Article XX $(\mathrm{g}) .^{20}$

In the Shrimp-Turtle Case, ${ }^{21}$ the WTO Appellate Body concluded that a U.S. prohibition on shrimp harvested by methods that are harmful to sea turtles was unjustifiable and arbitrary, regardless of the fact that the U.S. banned the use of such methods by its own tuna fleet, and that the sea turtles species protected by the prohibition were recognized to be in danger of extinction. The Appellate Body revisited the conflict in $2001{ }^{22}$

\section{International (Multilateral) Environmental Agreements AND THE WTO}

Because the environment overlaps states territorial divisions, countries are forced to enter into international agreements to protect shared environmental resources. ${ }^{23}$ Such agreements may include the prohibition of imports and exports of products if the importing and exporting countries are not parties to the agreement or are not complying with it. ${ }^{24}$

From a strategic perspective, these agreements should include obligations that encourage the participation of as many countries as possible, avoiding that nonmembers States become "havens" that jeopardize the effectiveness of the agreement (the free rider problem). ${ }^{25}$

If United States - Restrictions on Imports of Tuna, Aug. 16, 1991, GATT B.IS.D. (39) Supp.) at 155 (1993) (unadopted Panel Report), teprinted in 30 T.L.M. 1594 (1991).

${ }^{17}$ United States -. Restrictions on Imports of Tuna, June 1994, P 5.5, reprinted in 33 I.L.M. 839.

${ }^{18}$ United States - Impott Prohibition of Certain Shrimp and Shrimp Products: Report of the Appellate Body, WT/DS58/AB/R (Oct. 12, 1998).

19 Patricia Isela Hansen, The Imprat of the WTO and NAFTA on USS. Law, 46 J. OF LEGAL EDUC., 569, 576 (1996).

20. See Hansen, Trantareng; supra note 10, at 1027 and 1031 .

2. Id. at 1053 .

22 See Howard F. Chang, Enminmental Trade Meanmes, The Sbrimp-Turte Rutings, and The Ordinary Menning of the Text of the GATT, 8 Chap. I. Rev. 25 (2005) (atguing that the 2001 ruling by the Appellate Body confirms and interpretation of the 1998 shrimp-turtle decision that preserves broad leeway for the use of envirotimental trade measures.)

2.3 See BROWN WEISS \& JACKSON, supra note 4, at 30.

${ }^{24}$ Id

25 Id. at 30.31 . 
The Montreal Protocol on Substances that Deplete the Ozone Layer, the Convention on International Trade in Endangered Species (CITES), the Basel Convention on the Transboundary Movement of Hazardous Waste, and the Cartagena Protocol on Biosafety ate illustrative examples of multilateral environmental agreements that restrict trade in controlled items.

For international trade law, the issue is "whether these agreements violate Article I (Most Favored Nation Treatment), III (National Treatment) and XI (Prohibition of Quantitative Restrictions) of GATT 1994, and if so, whether Article XX exceptions apply to make them nonetheless GAT $\Gamma$ consistent."

\section{The Product/Process Distinction}

GATT Treacy focuses on products, whereas the production process is generally accepted as falling outside the reach of the non-discriminatory principles of national treatment and most-favored-nation. However, under an environmental perspective, "[p]roducts that are produced by processes that pollute the air, water or land, or that destroy living natural tesources and their habitats thay be far more destructive of sustainable development than the products themselves."27

However, more recent trade and environment disputes, such as the Tuna-Dolphin I and II Cases and the Shrimp-Turtle Case, point that this distinction is highly disputable, noting that processes can both endanger the envitonment and distort trade. Trade distortion happens if certain countries are allowed to work under lax environmental standards in the making of products that compete with those of countries complying with rigid environmental laws and regulations (in a sort of subsidy).

But if these concerns are worthy of the trade community's attention, the merit of the product/ process distinction is attributable to the fact that GATT closes the door to using a variety of regulatory differences to pose barriers to trade, undermining the goal of trade liberalization. ${ }^{28}$

The issue here, as correctly tecall Brown Weiss \& Jackson, is "how to develop criteria by which to judge whether trade barriers based on processes are an appropriate accommodation of the competing trade and environment policies, or whether on the contrary the barriers are really protectionist measures in the guise of environmental (or other process) considerations." 29

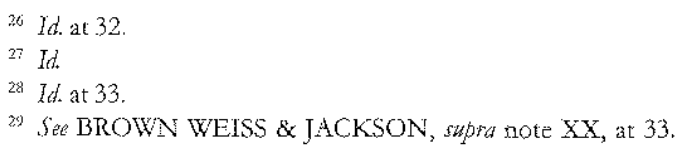


The retread tite dispute falls mostly under the category of national measures to protect the domestic environment, whereas the central issue before the dispute settlement bodies is whether the import ban on rettead tites are grounded on genuine environmental interests that could trump commercial commitments assumed by the involved countries regionally and multilaterally.

\section{ParT II.}

\section{THE MERCOSUR DISPUTES OVER TRADE IN RETREAD TIRES ${ }^{30}$}

\section{A. The Brazilian Litigation}

On September 17, 2001, a MERCOSUR panel was fotmed, pursuant the Brasilia Protocol, to decide a dispute presented by Unuguay against Brazil, concerning trade practices maintained by Brazil affecting trade in retreated tires. In this case, the parties and the panel overlooked the linkage between trade and environment. The legal issue before the panel was whether the Brazilian import ban on retread tires was consistent with MERCOSUR law.

Uruguay claims that Portaria $n^{\circ} 8$ of Septembet 25,2000 of the Brazilian Secretariat of Foreign Trade (SECEX), which imposes an import ban on used and retreated tires (classified under codes 4012.20 and 4012.10 of the Combined Nomenclature, respectively), violates MERCOSUR law, more precisely: Decision no $22 / 00$ of June 292000 of the Common Market Council (that prohibits the adoption of measures, of any nature, restrictive of reciprocal trade), Atticle 1 of the Asuncion Treaty (that establishes the objective of consolidating the process of integration and economic cooperation) and Articles 1 and 10(2) of Annex 1 to the Asuncion Treaty (that bans all non-tariff restrictions), and general principles of international law (Estoppel).

Brazil, on the other hand, denies Uruguay's allegations that Portaria $N^{\circ} 8 / 00$ is incomparible with MERCOSUR law.

With regard to Portaria $\mathrm{N}^{\circ} 08 / 00$, Brazil states this Portaria regulates the importation of used items. To Brazil, retreated tires are used goods, regardless of the fact they have been subject to any sort of industrial process aiming at augmenting its longevity. In this sense, Brazil states that MERCOSUR Committee of Technical Rules, in 2000, issued Technical

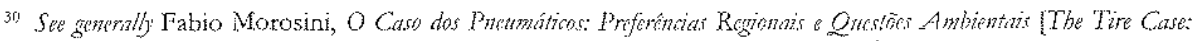
Reginal Preferences and Emimmental lsswe], PONTES: ENTRE O COMERCIO E O DESENVOLVIMENTO SUSTENTÁVEL 12 (October-December, 2005), available at wwwictsd.org/monthly/ pontes. 
Norms $n^{\circ} 224: 2000$ and 225:2000, which according to the Brazilian government, define a retreated tyre as a used good that underwent a process of reutilization of an existing good. ${ }^{31}$ In addition, Brazil states that Argentina also bans the importation of retreated tires, based on the findings that retreated tires are used tires, to which importation is prohibited based on the context of MERCOSUR's automotive policy. ${ }^{32}$ For these reasons, Brazil challenges Uruguay's argument that Brazil does not consider retreated tires used goods and atgues that retreated tires fall under the authority of Portaria $n^{\circ} 8 / 91$, which regulates the importation of used goods. ${ }^{33}$

By adopting Portaria $n^{\circ} 8 / 00$, Brazil states that it was trying to reprimand the importation of retreated tires that was taking place due to gaps in the information system for foreign trade, the SISCOMFX. ${ }^{34}$ In this sense, Portaria $n^{\circ} 8 / 00$, in regulating the importation of retreated tires, performs an interpretative function to previous regulations. ${ }^{35}$ By no means it establishes a new prohibition to include a ban on the importation of retreated tires. ${ }^{36}$ Thus, Portatia $n^{\circ} 8 / 00$ does not violate Decision $n^{\circ} 22 / 00$ because the former merely clarifies the importation system of used goods in Brazil. ${ }^{37}$

The Panel's Interpretation and Application of MERCOSUR Law

Portaria $n^{\circ} 8 / 00$

Unuguay sustains that Brazilian lan:s and regulations concerning trade in retreated tires and related commonial practices in Brazil support the conclusion that Brazil did consider used and retreated tires as two different goods, subject to distinct legal treatment.

First, as for the body of law emanated from different Brazilian authorities during the almost ten-year period that divided one Portaria from another, the Tribunal rejects the argument presented by Brazil, sustaining that it could not be representative of Brazil's official legal understanding on the issue..$^{38}$ Brazil advocated that the laws and regulations presented by Uruguay as evidence of a differentiated legal treatment conferred to retreated atkd used tires are from different sectors of the Brazilian public administration that does not have the authority to regulate foreign commetce in Brazil. ${ }^{30}$ In tesponse to this claim, the

3! See Arbitral Award VI - Tyres - from Uruguay to Brazil -.. 01/09/2002, at 11, at'allable at wrww.MERCOSUR.org.uy (last visited May 9, 2005).

${ }^{32} \mathrm{Id}$

${ }^{33} I d$

34 Id

3 Id at 9 .

${ }^{36}$ Id. at 9.

37 See Arbitral Award VI - Tyres - from Utuguay to Btazil -- 01/09/2002, at 10, atuiluble at wwwMERCOSUR.org.uy (last visited May 9, 2005).

38 Id at 20 .

${ }^{39} \mathrm{Id}$ 
Tribunal concludes that as matter of international law, Article 4 of the Project about State Responsibility, of November 2001, of the International Law Commission, "the behavior of any state institution will be considered as an act of state, regardless of the legislative, executive or judiciary function of this institution." ${ }^{\prime 41}$ Consequently, the Tribunal concludes that all the separate pieces of regulations and legislation issued by different institutions of the Brazilian government is representative of this country's legal understanding on the issue disputed in the present controversy. ${ }^{42}$

Second, as for the internal commercial practice performed by Brazil in that same timeframe, the panel takes into account the evidence presented by Uruguay, indicating that the import authotization of retreated tires from Uruguay amounted to a continuous and growing trade between that country and Brazil. In the Tribunal's view, this ongoing trade was warranted by the behavior of different institutions of the Brazilian public administration. ${ }^{43}$

In conclusion, the panel agrees with Uruguay that the import ban imposed on used tires by Portaria $n^{\circ} 8 / 91$ was never intended to extend to retreated tires, ${ }^{44}$ given the internal practice of Brazil in accepting the importation of Uruguayan retreated tires during a period of almost ten years that divided Portaria $n^{\circ} 8 / 91$ from Portaria $n^{\circ} 8 / 00$, indicating that the Brazilian public administration never considered retreated tires as used tires. ${ }^{45}$

\section{Resolution 109/94 of the Common Market Group}

Brazil sustains that Resolution 109/94, of February 15, 1994, of the Common Market Group subjects the legal treatment of used goods to the national legislation of the member states, including the definition of used goods. ${ }^{46}$

The panel emphasizes that Resolurion 109/94 establishes an exception to the Treaty of Asuncion and therefore should be interpreted restrictively. ${ }^{47}$ In addition, Uruguay argues that Resolution 109/94 does not support arbitrary changes in the legal systems of the member states, which affects trade inside MERCOSUR ${ }^{48}$ In that regard, the panel concludes that even though Resolution 109/94 establishes a recognized exception to the ongoing

\footnotetext{
${ }^{40} \mathrm{Id}$

4t $I d$

42. See Arbitral Awatd VI - Tyres - from Uruguay to Brazil - 01/09/2002, at 20, anatilable at www:MERCOSUR.orguy (last visited May 9, 2005).

4.3 Id. at 18.

44 id

45 Id. at 19 .

$461 d$ at 21 .

47 See Arbitral Award VI - Tyres -.. from Uruguay to Brazil - 01/09/2002, at 21, alailable at wanw MERCOSUR.org.uy (last wisited May 9, 2005).

${ }^{48}$ It
} 
legislative harmonization process in MERCOSUR, Portaria $n^{\circ} 8 / 00$ would not be justified under such exception because it contradicts established commercial practice in the region, i.e., the constant and growing trade flow of retreated tires. ${ }^{49}$

\section{Decision 22/00 of the Common Market Counil}

Decision 22/00 of June 29,2000, of the Common Market Council states that "[t]he "Member States shall not adopt any measure restrictive to reciprocal trade, regardless of the nature of the measure, but shall take into account the reservation established in Article 2(b) of Annex 1 to the Asuncion T'reaty."

Portaria $n^{\circ} 8 / 00$ is later in time to Decision $22 / 00$ of the Common Market Council and establishes a restriction to reciprocal trade..$^{50}$ Thus, the Tribunal concludes Portaria $n^{\circ} 8 / 00$ violates Decision 22/00 of the Common Market Council. ${ }^{51}$ 'The panel reasons that, whereas Decision $n^{\circ} 22 / 00$ does not modify the applicability of Resolution $n^{\circ} 109 / 94$ generally, it conditions the capacity of the member states to modify, from the date of the Decision's approval, the reach of their national regulations and legislation concerning the imposition of new restrictions to trade of used goods. ${ }^{52}$

\section{General Principles of Law: Estoppel}

Uruguay argues that Portaria $n^{\circ} 8 / 00$ contradicts: $:^{53}$ (a) the extensive commercial practice in Brazil, allowing the importation of retreated tires from Uruguay or third countries, and (b) the interpretation and application of the existing body of law related to the subject. matter. On these grounds, Uruguay sustains the confrontation of Portaria $\mathrm{t}^{\circ} 8 / 00$ with these two factual circumstances gives rise to a claim under the principle of "renire contra fuctum propriwm" or the principle of estoppel. ${ }^{54}$

Brazil, on the other hand, argues the principle of estoppel is not applicable to the disputed facts, because the alleged Brazilian commercial practices related to the importation of retreated tires were not constant and certain as to create legitimate expectations on third countries..$^{55}$

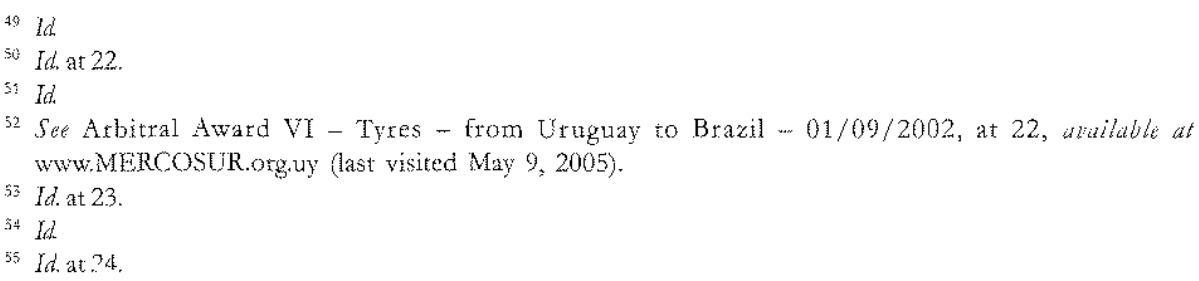


The panel concludes that the continuous commetcial trade in retreated tires between Brazil and Uruguay, and official declarations of Brazilian authoxities regulating directly or indirectly the importation of used and tetreated tires could create a legitimate expectation in Unuguay that, in confrontation with Portaria $n^{\circ} 8 / 00$, could qualify as a situation described in the principle of "venire contra fatum proprium." ${ }^{56}$ However, the panel preferred to take a different road, and stated that given the involved countries are members of an ongoing integration process promoted under the auspices of MERCOSUR, the decision-making body shall rely on principles of mutual trust, which bars the "venire contra factum proprium." 57

Finally, the panel rejects the allegations of the Brazilian government that deny the extensive trade flow in tetreated tires tecognized by official actors of the public administration of Brazil 58

On January 8,2002 , the panel decided that Portaria $n^{\circ} 8 / 00$ is not compatible with MERCOSUR law and ordered that Brazil adapt its laws to conform the Tribunal's legal findings. From the panel's findings that the referred trade practices maintained by Brazil affecting trade in tetreated tires are in violation of MERCOSUR law, it resulted that:

1. Brazil eliminated the ban for tetreated tires imported from other MERCOSUR countries by means of Portaria SECEX $n^{\circ} 2$ of March 8, 2002;

2. Presidential Decree $n^{\circ} 4592$ of February 11,2003 exempted retreated tires imported from other MERCOSUR countries from the financial penalties established under Presidential Decree ${ }^{\circ} 3919$ of September 14, 2001;

3. Article 55, paragraph 1 of Portaria SECEX n 17 of December 1, 2003 replaced and revoked Portaria 8/00. Article 39 of the new Portatia restated that import licences shall not be issued for used and retreated tires, with the exception of retreads originating in other MERCOSUR countries.

In face of the parties" "forgetfulness" of the link between the challenged trade measures and the protection of the environment and public health, it is worth asking whether the panel, according to MERCOSUR law, could have raised this issue ex officio. As far as WTO law goes, the answer to this question is NO. MERCOSUR has not yet faced this question, but it could be argued that, as a matter of public policy (ordre pulbici), the panel could raise the issue of envitonmental protection, even though the parties did not do so. ${ }^{59}$

56 $1 d$

57 See Arbitual Award VI - Tyres ... from Uruguay to Braziz ... 01/09/2002, at 24, aliailable at www.MERCOSUR org.ty (last visited May 9, 2005).

$58 I d$

59 Preamble to the Asuncion Treaty (establishing that the economic integration process anongst the member States of MERCOSUR shall take into account the prescrvation of the enviroment). 
Moreover, had Brazil recognized the links of the present dispute with environmental ptotection issues, it could have invoked Article 50 of the Montevideo Treaty, which allows for the adoption of measures that, if not for environmental teasons, would be contrary to the efforts of trade liberalization within the member States of the Latin. American Association of Integration Law (ALAD). Article 50 of the Montevideo Treaty has been incotporated into MERCOSUR law by means of Article 2(b) of Annex I to the Asuncion Treaty, which states that trade resttictions can be defined as any measure that is administrative, financial, or pertains to curtency exchange, under which a State bans or makes it difficult, by unilateral decision, reciprocal trade; and establishes that measures adopted under the circumstances prescribed in Article 50 of the Montevideo Treaty shall not constitute a trade restriction.

Soon after the MERCOSUR panel issued its decision, the media in Brazil devoted close attention to the negative environmental impacts of the panel's findings. The main newspapers in Brazil published articles with headings such as "Brazil May Become Garbage Deposit for World Tires".

\section{The IMPaCt of MERCOSUR on Brazilian LaW?}

The Fedetal Public Attorney's Office, in a class action, challenged Presidential Decree $\mathrm{n}^{\circ} 4592$ of February 11,2003, which exempted retread tires imported from other MERCOSUR countries from the financial penalties established under Presidential Decree $n^{\circ} 3919$ of September $14,2001 .^{61}$

'The class action brings up environmental arguments not yet raised by Brazil in the MERCOSUR litigation. The Federal Public Attorney's Office argues that the Brazilian ban on retread tires is based on environmental grounds. In other words, the ban is justified by the adverse effects liberalizing trade in retread tires in Brazil has on the environment itself and on public health. The precautionary principle, which allows for the adoption of certain measures to protect the environment even though the risks are not yet scientifically proved, was one of the main arguments raised in this class action to justify upholding the ban. In addition, the Federal Public Attorney's Office referred to Article 50 of the Montevideo Treaty, which permits the adoption of measures, aimed at protecting the environment, which would otherwise constitute trade restrictions. The class action concludes by requesting that the Brazilian measure which subjects the importation as well as the marketing, transportation, storage, keeping or keeping in deposit of retreated imported tires to a fine of $\mathrm{R} \$ 400$ per unit be upheld, without exceptions!

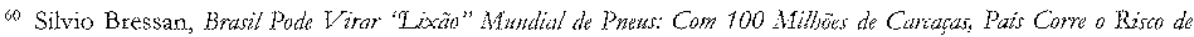
Reveber Sobras da Europa TYia Mercosml, Jonal O Estado de São Paulo, 03.17.2003.

61 See Ação Civil Pública Ministério Público Federal contra União Federal, Joinville, Santa Catarina State, 06.02 .2003 (on file with authot). 
From an economic integration policy perspective, it is interesting to note that nowhere in the class action, has the Federal Public Attorney's Office directly questioned the constitutional validity of the MERCOSUR Report. As pointed out by Celso Amorin, Minister of External Relations, "for a country that aspires to be the MERCOSUR leader, questioning the Arbitral Award would be like 'a shot on ones own foot', because later Brazil would lose its legitimacy in other disputes of its interest." ${ }^{\prime \prime 2}$ However, at least one Brazilian international law scholar, Cláudia Lima Marques, has argued for the unconstitutionality of the panel Report and its illegality pursuant existing public international law.

In Professor Lima Marques' view, the MERCOSUR decision violates the following articles to the Brazilian Constitution: Article 1 (sovereignty and human dignity), Article 4 (reception of the Montevideo Treaty), Article 49 (delegated competency for Treaties), Article 84 (limited competency for intetnational relations), Article 92 (judicial control), Article 109 (supremacy of the fundamental rights conferred by the Constitution in face of Treaties), Article 170 (principles governing the national economy), and Article 225 (fundamental right of protection of the environment by the State) ${ }^{64}$

As to the supposed illegality of the MERCOSUR decision in the light of governing principles of public international law, Professor Lima Marques' argues the 1991 Asuncion Treaty, which institutionally creates MERCOSUR, is a consequence of the broader 1980 Montevideo Treaty, which creates the Latin American Association of Integration Law: As a matter of Treaty interpretation, the Asuncion Treaty is in a hierarchy inferior to the Montevideo Treaty, which entails that the former has to conform the latter. Therefore, a MERCOSUR decision that ignores and confronts provisions pursuant to the Montevideo Treaty (Article 50 ) violates genetal principles of public intenational law. ${ }^{6.5}$

\section{B. The Argentinean Litigation}

In 2005 , a new panel was constifuted ${ }^{66}$ pursuant the Olivos Protocol, to decide on the consistency of the Argentinean ban on retread tires with MERCOSUR law ${ }^{67}$ In this dispute, the Tribunal accepted the Argentinean defense against Uruguay based on Article 50 of the Montevideo Treaty, which allows for trade testriction amongst member States, provided the restriction is based on legitimate environmental grounds. ${ }^{68}$

\footnotetext{
62 See Bressan, supra note 62 .

6. See Claudia Lima Marques, unpublished manuscript (on file with author).

${ }^{64} \mathrm{Id}$.

${ }^{6}$ Id

6if Veja: http://wwtwercosur.int/msweb/SM/pt/Controversias/TPR/TPR_Tribunal\%20 AdHoc_Laudo\%20Nenmaticos_PT.pde

67 Morosini, O Caso dos Puenmaticos, suppa note 32, at 14.

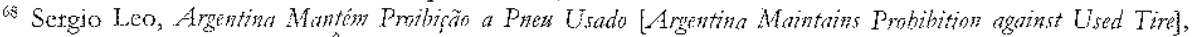
JORNAL VALOR ECONOMICO, November 28,2005 , antilable at www.valoronline-com.br (last visited November 15, 2005).
} 
The two contradicting MERCOSUR decisions concerning apparently the very same issue raise important questions to the future development of MERCOSUR law, both in terms of conflicts involving trade and environment, and in relation to the dispute settlement mechanism.

For the first time in MERCOSUR history, the Appellate Body was called on to decide the legal treatment conferred to trade in retread tires in the dispute between Uruguay and Argentina ${ }^{69}$ The Appellate Body, revoking the panel's report, decided that the Argentinean law that bans the importation of retread tires is not compatible with MERCOSUR law: ${ }^{70}$

\section{Part III.}

\section{THE WTO DISPUTE OVER TRADE IN RETREAD TIRES}

On Jatuaty 7, 2004, the European Community (EC) published, in the Official Journal of the Eutopean Union, a Notice of Initiation of an examination procedure conceming obslatles to trade within the meaning of Council Regulution (EC) $n^{\circ} 3286 / 94$, consiting of trade practices maintained by Brazil in relation to imports of retreated tires [heseinafter Notice] ${ }^{71}$

The Nodice resulted from a complaint brought by the Bureut Intemational Permanent des Associations de Vendeurs et Retuptetsrs de Pneumatique Permanent International Office of the Tire Sellers and Retreaders Association] (BIVAPER), an international trade association representing the interests of manufacturers of retreated tires within the Eutopean Union. BIPAVER congregates national associations from Denmark, Finland, Italy, Portugal, Spain, Sweden and the United Kingdom.

The Notice asserts that the Brazilian measures that give rise to the investigation procedure are:

(1) Portaria $n^{\circ} 8$ of September 25, 2000 of the Brazilian Ministry of Development, Industry and International Commerce, which bans the importation of tetreated tires by prohibiting the issuance of import licences for retreated tires imported as consumer goods or taw material;

(2) Presidential Decree $n^{\circ} 3919$ of September 14, 2001, which subjects the importation as well as the marketing, transportation, storage, keeping or keeping in deposit of retreated imported tires to a fine of $\mathrm{R} \$ 400$ per unit.

69) Veja:http://www.mercosur.int/msweb/SM/es/Controversias/TPR/TPR_Laudo0012005_Importacion $\% 20$ de $\% 20$ Neumaticus $\% 20$ Rtmoldeados.pdf. Veja também; http://wwwmercosurint/ $\mathrm{msweb} / \mathrm{SM} / \mathrm{es} /$ Controversias/1PR/TPR_latudo001-2006_Recurso\%20de\%20Aclatatoria.pdf.

70 Id

" Sét Bazil imports of retreated tires notice of initiation http:/trade-infocec.eu.int/docib/html/ 115548.htm (last visited May 23, 2005). 
The Notice classifies the Brazilian measures as GAT'T-inconsistent, by discriminating between imported and domestic like products, in violation of Articles I.1 (General MostFavoured-Nation Treatment), III.4 (National Treatment on Internal' Taxation and Regulation) and XI.1 (General Elimination of Quantitative Restrictions) of GATT 1994, without being justified under neither the exceptions of Article XX (General Exceptions), nor under Articles 2.1,2.2 and 2.4 (Preparation, Adoption and Application of Technical Regulations by Central Government Bodies) of the WTO Technical Barriers to Trade Agreement (TBT Agreement).

The Notice claims that the challenged Brazilian trade measures had a significant negative impact of Community exports of retreated tires. Prior to the introduction of the ban, Community exports of retreated tires amounted to approximately two million per year, equivalent to an estimate of 25 per cent of the Brazilian matket for such products. It is also stressed that the Brazilian measures tesulted in company closures and job losses within the Community. In addition, it primarily draws attention to the negative policy implications of permitting least-favorable treatment of retreated tires originated from $\mathrm{W}^{\prime} \mathrm{TO}$ member states outside MERCOSUR. Secondly, the Notice addresses the more inmediate reasons, i.e., loss of production of retreated tires and job losses within the Community. Finally, the Notice considers that there is enough evidence to justify initiation of an examination procedure to consider the legal and factual issues involved in accordance with Article 8 of the Trade Barriers Regulation. ${ }^{72}$

On Septenber 13, 2004, the European Commission Directorate-General for Trade published a non-confidential version of the Report to the Trade Barriers Regulation Committee [hereinatter Report.] $]^{\text {t/3 }}$ The Report concluded the investigation had tevealed clear violations of WTO provisions, notably Articles XI:1, III:4, I:1 and XIII:1 of the GATT 1994 thar cannot be justified on grounds of environmental or health protection.

Combined with severe adverse trade effects these violations have caused, the Report recommended that Brazil be given until October 2004 to withdraw the measures. Otherwise, the Commission would request WTO consultations in accordance with the rules of the Dispute Settlement Understanding (DSU).

72 The Trade Bartiers Regulation is a legal instrument that gives the right to Community enterptises and industries to lodge a complaint, which obliges the Commission to investigate and evaluate whether there is evidence of violation of international trade inles resulting in adverse trade effects. The result is that the procedure will lead to either a mutually agreed solution to the problem or to resort to dispute settement. Article 8 establishes the Community Examination Procedure.

${ }^{75}$ See Report to the Ttade Bartiers Regulation Committee concerning an obstacle to trade, within the meaning of Council Regrlation (EC) No. 3286/94, consisting of trade practices maintained by Brazil affecting trade in retreaded tres [hereinafter Report], antilable at http://trade-infoceceu.int/doclib/ cfm/doclib_section.cfm?sec $=205 \&$ lev $=2 \&$ (last visited May 23, 2005). 
On May 2, 2005, because diplomatic negotiations between Brazil and the European Communities had failed to reach a satisfactory solution, the Commission lodged a Commission Decision concerniny the measures necessary as regards an obstacle to trade constituted by trade practices maintained by Brazil affecting trade in retrated tires [hereinafter Decision]. ${ }^{74}$ The Decision concluded:

(1) The Brazilian Government's imposition of an import ban on retreated tires and the related financial penalties appear to be inconsistent with Brazil's obligations under the Martakech Agreement Establishing the World Trade Organization and, in particulat, provisions of the General Agreement on "Fariffs and Trade 1994, and constitutes an obstacle to trade within the meaning of Article 2(1) of Regulation (EC) $\mathrm{n}^{\circ} 3286 / 94 ;^{75}$

(2) The Community will initiate dispute settlement proceedings against Brazil under the Understanding on Rules and Procedures Governing the Settlement of Disputes and other relevant WTO provisions to secure removal of the obstacles to trade.

In January 2006 , at the request of the EC, the WTO established a panel, under the Dispute Settlement Understanding, to analyze whether the Brazilian import ban on retread tires is GATT-consistent. ${ }^{76}$ To date, Brazil has not yet issued any formal response to the claims brought by the $\mathrm{EC}$, concerning the alleged inconsistency of the Brazilian measures with GATT 1994.

In case the EC decides to challenge the consistency of the Brazilian measures with the GATT 1994, it is likely that Brazil will justify the import ban under the General Exceptions of Article XX of GATT, letters (b) and (g). Article XX GATT provides that, if "a measure is not applied in a manner which would constitute a means of arbitrary or unjustiffable discrimination betuen countries where the same conditions prevail, or a disguised restriction on intemational trade" (Chapeau of Article XX), a country may adopt measures that would otherwise constitute a trade restriction if not for its legitimate goal of: (b) protection of human, animal or plant life or health, and ( $\mathrm{g}$ ) conservation of exhaustible natural resources.

it Avilable at http: $/ /$ trade-infocec.eu.int $/$ doclib $/ \mathrm{cfm} / \mathrm{doclib}$ section.cfm?sec $=205 \&$ lev $=2 \&$ (last visited May 23, 2005).

75 Under Article 2(1), "obstacles to trade shall be any trade practice adopted or maintained by a thitd country in respect of which international rrade rules establish a right of action. Such a right of action exists when international trade rules either prohibit a practice outright, or give another party affected by the practice a right to seek elimination of the effect of the practice in question."

76 W'T/DS322/1, aluilable at http://www.wto.org/english/tratop_e/dispu_e/cases_e/ds332_e.htm (last visited Match 31, 2006). 
If Brazil decides to invoke the General Fixceptions of Article XX to justify the import ban on retread tires, it will have to prove that the import ban falls within the range of policies designed to protect human life or health and that the inconsistent measures for which the exception is invoked are necessary to fulfill the policy objective. ${ }^{n}$

There seems to be enough evidence that the measures adopted by Brazil, restricting imports of retread tires may give tise to a defense based on envitonmental grounds. First, it is cleat that the unrestricted importation of retread tires, and its storage, by itself, poses serious environmental risks. Second, the water from the rain accumulated in the interior of theses tires is a perfect habitat for the procreation of mosquitoes imposes scrious public health concerns. Third, the burning of these tires, when they become no longer usable, discharges toxic substances harmful both to the environment and to public heal th. On top of that, concerning the lack of scientific certainty as to the actual environmental risks of unrestricted imports of retread tires, Brazil could arguably develop a defense based on the precautionary principle. ${ }^{78}$

In this sense, if thete exists no least restricuve ways to address the health risks imposed by the unrestricted importation of retread tires, it seems sensible to invoke the Gencral Exceptions of Article XX GAT't.

It would follow that the risks to public health originated from storing tires with rainwater in their interior, risking, at a further level, the development of dengue and yellow fever epidemic, would justify the invocation of Article XX (b), that provides for the adoption of measures that are necessary to protect human, animal or plant life or health. Second, the

7 See Panel Report, United States - Gitsoline, pata. 6.20; Panel Repore, EC-Asbestor, para. 8.169; jee also Appellate Body Report, EC-Ashestos, paras. 157 163.

${ }^{78}$ But see EC ... Hormones: "The status of the precautionary principle in international law continues to be the subject of debate among acadenics, law practitioners, regulators and judges. The precautionary principle is regarded by some as having crystalized into a general principle of customary intemational environnental law. Whether it has been widely accepted by Members as a principle of genetal or customaty international law appears less than clear. We considex, however, that it is unnecessary, and probably imprudent, for the Appellate Body in this appeal to take a position on this important, but abstract, question. We note that the Panel itself did not make any definitive finding with tegard to the status of the precautionaty principle in international law and that the precautionary principle, at least outside the field of international cnvironmental law, still awaits authoritative formulation." Para. 123, WT/DS26/AB/R, WT/DS48/AB/R.

79 C. Jopan - Agrinltural Produts IT: "Article 5.6 of the SPS Agreement prohibits SPS measures that are more trade-restrictive than required to achieve a Menber's appropriate level of protection. According to the footrote to Article 5.6, a measure is considered more trade-restrictive than tequired if there is another SPS measure which:

(1) is reasonably available taking into account techaical and econonic feasibility;

(2) achieves the Member's appropriate level of sanitary or phytosanitary protection; and

(3) is significantly less testrictive to trade than the SPS measure contested.

As we have stated in our Report in Akstratis - Salmon, these three clenents are cumulative in nanure." Pata. 95, WT $/ D S 76 / A B / R$. 
toxic substances liberated from the burning of these tires could be addressed, which endangers the environmental and public health, could fall under letter (b) (toxic substances are harmful to human, animal and plant life and health) and letter (g), for measures relating to the conservation of exhaustible natural tesources (the air, earth and water could arguably qualify as exhaustible natural tesources).

However, letter $(g)$ of Article XX also states that in order for a measure to fall under the General Exceptions, it has to be "made effective in conjunction with restrictions on domestic production or consumption". Concerning the application of similar measures to the domestic retread tires industry; it bears mentioning that under Resolution $n^{\circ} 258$ of the National Council of the Environment (CONAMA), presided by the Ministry of the Environment, of August 26, 1999, in force since 2002, domestic producers of new tires and importers of tires are obliged to give an adequate environmental destination to such tires. On March 21, 2003, CONAMA issued Resolution $n^{\circ} 301$, which amends Resolution $n^{\circ} 258$, to extend the obligation to give environmentally adequate destination to imported retread tires.

But, if, on the one hand, Brazil implemented regulation to monitor the environmental impact of the activity of producers of new tires and importers of new and tetread tires, on the other, it is disputable the treatment conferred to domestic tire retreading industry. Maybe the lobby from tire retreaders that operate in Brazil was strong enough to leave these companies outside the scope of application of CONAMA Resolutions Nos. 258 and 301. Moreover, according to the EC, the enforcement of CONAMA Resolutions in Brazil has been problematic. ${ }^{\text {sin }}$

Lastly, if Brazil is able to convince the panel that the import ban falls under the general exceptions of Article XX, letters (b) or (g) - or both, Brazil still needs to pass the scrutiny of the chapeatu of Article XX, i.e., that the "measure is not applied in a manner which nould constitute a means of arbitrary or unjustifuble discrimination betwen conntries where the same conditions prevall, or a disyulised restriction on international trade." ${ }^{31}$

80 Cf. Roformuluted Gitiolini Case, where the Panel held that the Gasoline Regulations were inconsistent with Article MI:4 GATT, which requires that imported like products nust be treated no less favorably than like domestic products with respect to laws and regulations.

s) In October: 1998, the WTO Appelliate Body decided that a U.S. ban on shtimp harvested by methods that are harmful to sea turtles was "unjustifiable" and "arlitrary," even though the United States prohibited the use of these methods by its own tura fleet, and even though the sea turiles species protected by the ban were recognized to be in danger of extinction. 


\section{Conclusion}

The outcome of the tire case in the WTO is unpredictable. On the one hand, the rejection of the environmental exceptions would not come as a surprise in the light of past GATT'/WTO trade and environment jurisprudence. On the other hand, WTO's recognition of the legitimacy of the environmental exception in the present case would yield important policy implications for the international community and MERCOSUR especially.

First, WTO would create a precedent in favor of environmental protection to the detriment of free trade. Second, as for MERCOSUR specifically, a W'O decision recognizing the supremacy of the environmental protection over purely commercial interests could certainly have a direct impact on the MERCOSUR litigation. But most importantly, if Brazil succeeds in its environmental defense, it will be signaling to the international community that the protection of the environment is not an exclusive concern of developed countries.

\section{BibLIOGRAPHY:}

Jagdish Bhagwati, The Demand to Reduce Domestic Diversity among Trading Nations, in JAGDISH BHAGWATT \& ROBERT E. HUDEC (eds.), FAIR TRADE AND HARMONIZATTON: PREREQUISTTES FOR FREE TRADE?, V1 (1996);

Jagdish Bhagwati \& T. N. Srinivan, Trade and the Enironment: Does Enimonmental Dinersity Detract from the Case for Free Trade? in JAGDISH BHAGWATI \& ROBERT E. HUDEC (eds.), FAIR TRADE AND HARMONIZATION: PREREQUISITES FOR FREE TRADE?, V1 (1996);

EDITI BROWN WEISS \& JOHN H. JACKSON (eds.), RECONCILING ENVIRONMENT AND TRADE (2001);

Alessandra Casella, Free Trade and Evolning Standards, in JAGDISH BHAGWATI \& ROBERT E. HUDEC (eds.), FAIR TRADE AND HARMONIZATION: PREREQUISITES FOR FREE TRADE?, V1 (1996);

Carolyn L. Deere \& Daniel C. Esty, Trade and the Emironment in the Americas: Onemien of Key Issues, in GREENING THE AMERICAS: NAFTA'S LESSONS FOR HEMISPHERIC TRADE (Carolyn L. Deere \& Daniel C. Esty eds.) (2002);

DANIEL C. ESTY, GREENING THE GATT: TRADE, ENVIRONMENT', AND THE FUTURE (1994);

Patricia Isela Hansen, Transpareng;, Standards of Revien, and the Use of Trade Measures to Protest the Global Enwionment, 39 VA. J. INT'L I. 107 (1999);

JOFIN H. JACKSON, WILIIAM J. DAVEX \& ALLAN O. SYKES, JR., LEGAL. PROBLEMS OF IN'TERNATIONAL ECONOMIC RELATIONS ( $4^{\text {th }}$ ed., 2002); 
JOHN H. JACKSON, WILIIAM J. DAVEY \& ALLAN O. SYKES, JR, DOCUMENTS SUPPLEMENT TO LEGAL PROBLEMS OI INTERNATIONAI. ECONOMIC REILATIONS (4 $4^{\text {ti }}$ ed., 2002);

Alvin K. Klevorick, Reflections on the Race to the Bottom, in JAGDISH BHAGWATT \& ROBERT E. HUDEC (eds.), FAIR TRADE AND HARMONIZATION: PREREQUTSITES FOR FREE TRADE?, V1 (1996);

David W. Leebron, Ljing Down mith Prowustes: An Anabisis of Harmonization Clains, in JAGDISH BHAGWATI \& ROBERT E. HUDEC (eds.), FAIR TRADE AND HARMONIZATION: PREREQUISITES FOR FREE TRADE?, V1 (1996);

Arik Levinson, Environmental Regulations and Industry Yocation: Intemational and Domestic Evidene, in JAGDISH BHAGWATI \& ROBERT E. HUDFC (eds.), FAIR TRADE AND HARMONIZATION: PREREQUISITES FOR FREETRADE?, V1 (1996);

Fabio Morosini, Repensando Estratégias de Regulação Ambiental: Lições a partir da Experiência da União Emropéiue do NAFTA, 38 Revista de Direito Ambiental (São Paulo, RT ed.) 2005 [Republicado em 40 Revista de Dircito Ambiental (São Paulo, RT ed.) 2005].

, O Caso dos Pnenmáticos: Prefertencias Regionais e Questôes Ambientats, PONTES, Outubro - Dezembto 2005.

$\rightarrow$ El caso de los neumáticos en la OMC: Preferencias regionales y cuestiones ambientales, PUENTES, Enero - Febrero 2006.

Eric Neumayer, Trade Measures in Multilateral Enmironnthal Agreenthts and the WTO Rules: Potential for Conflict, Scope for Reconcliation, Aussentirtsclaft 55, no. 3 (2000), Pp. 403. 426;

Richard Parker, The Use and Abuse of Trade Leveruge to Protert the Global Commons: What We Can Learn from the Tuna-Dalpbin Conflut, 12 GEO. INT'L T.. REV. 1 (1999);

Joe R. Paul, Free Trade, Rugulatory Competition and the Autonomous Market Fallacy, 1 COIUUM. J. EUR. L. 29 (1995);

Ellen R. Shaffer, Howard Waitzlsin et al., Globu/ Trade and Public Health, AMERICAN JOURNAL OF PUBLIC HEALTH, JANUARY 2005, Vol 95, 10¹;

Gregory C. Shaffer, The World Trade Organization ander Challenge: Demoracy and the Law and Politics of the WTO's Treatment of Trade and Environment Matters, 25 Harv. Envu. L. Rev. 1 (2001);

John Douglas Wilson, Capital Mobility and Emironmental Standards: Is There a Theontioul Basis for a Race to the Bottom? in JAGDISH BHAGWATT \& ROBERT E. HUDEC (eds.), FAIR TRADE, AND HARMONIZATION: PREREQUISITES FOR FREE TRADE?, V1 (1996);

Symposia; Judicialization and Globalization of the Judiciary, TEX. IN'T"LLLJ. 2003/2004;

Symposium: The Boundaries of WTO Law, AM. J. INT'L L., Vol. 96, n¹, Jan., 2002. 